\title{
Enteric outbreak surveillance in British Columbia, 2009-2013
}

\author{
Taylor $\mathrm{M}^{1^{*}}$, Galanis $\mathrm{E}^{1,2}$, \\ BC Enteric Outbreak Summary Working Group: Forsting $\mathrm{S}^{3}$, Gustafson $\mathrm{L}^{4}$, Ip $\mathrm{J}^{3}$, Jeyes $\mathrm{J}^{5}$, \\ Lem $\mathrm{M}^{4}$, Murti $\mathrm{M}^{4}$, Nowakowski $\mathrm{C}^{6}$, Ritson $\mathrm{M}^{3}$, Stone $\mathrm{J}^{4}$, Tone $\mathrm{G}^{7}$
}

${ }^{1}$ BC Centre for Disease Control, Vancouver, BC

${ }^{2}$ School of Population and Public Health, University of British Columbia, Vancouver, BC

${ }^{3}$ Vancouver Coastal Health Authority, Vancouver, BC

${ }^{4}$ Fraser Health Authority, Surrey, BC

${ }^{5}$ Interior Health Authority, Vernon, BC

${ }^{6}$ Vancouver Island Health Authority, Victoria, BC

${ }^{7}$ Northern Health Authority, Prince George, BC

*Correspondence: marsha.taylor@bccdc.ca

\section{Abstract}

Background: Understanding enteric disease outbreak sources, burden of illness, mode of transmission and use of interventions informs planning, policy development and prevention programs.

Objective: To describe trends in enteric disease outbreaks investigated in British Columbia (BC) between 2009 and 2013.

Methods: An analysis was conducted of enteric disease outbreaks that had been entered into a national, secure web-enabled outbreak reporting system using the Canadian Network for Public Health Intelligence $(\mathrm{CNPHI})$ and investigated in BC between January 1, 2009 and December 31, 2013. The data included information on pathogen, number of cases, hospitalizations, deaths, setting, mode of transmission, source, factors that contributed to the outbreak and interventions. Residential facility-based viral outbreaks and outbreaks associated with international travel were excluded.

Results: There were 104 outbreaks investigated in BC between 2009 and 2013. Ninety-three were reported by $\mathrm{BC}$ organizations and 11 were national outbreak investigations reported by the Public Health Agency of Canada (PHAC). There was an average of 21 outbreaks per year. Overall, the annual rate of foodborne outbreaks in BC was 2.8 per one million population. Seventy-nine (76\%) outbreaks had a pathogen identified, most commonly norovirus, Salmonella and E. coli. There was a total of 108 hospitalizations (3.8\% of all cases) and two deaths ( $0.1 \%$ of all cases); one caused by botulism, the other by E. coli O157. Food service establishments were the most common setting (33.7\%), followed by the community (24.0\%) and private functions (12.5\%). The food types most often reported were fruits and vegetables, meat and seafood. The data showed a pathogen-food source combination between Salmonella and eggs.

Conclusion: This is the first publication summarizing trends in enteric disease outbreaks in BC including assessing sources, burden and interventions. Ongoing reporting and analysis of outbreak data in BC will allow for improved assessment of trends in sources and pathogens over time and further understanding of the effectiveness of interventions associated with outbreaks.

\section{Introduction}

There are an estimated 552,209 cases of domestically-acquired foodborne illness in British Columbia (BC) each year (unpublished data, BC Centre for Disease Control and Public Health Agency of Canada, 2014). Although only a small proportion of these cases are associated with confirmed outbreaks (0.8-2.5\% of all cases) (1), outbreaks are a valuable source of information on sources of illness, burden of illness, modes of transmission and interventions (2). This information can be used by public health authorities, policy-makers, 
food safety professionals and the food industry to set priorities and to plan and implement prevention programs. The province of BC implemented enteric disease outbreak surveillance in 2008 to describe trends, improve understanding, conduct source attribution and evaluate interventions and resource use.

The objective of this study is to describe trends in enteric disease outbreaks investigated in BC between 2009 and 2013 as well as to conduct source attribution and describe interventions.

\section{Methods}

Gastroenteritis epidemics are reportable in BC (3). In August 2008, a national, secure web-enabled outbreak reporting system, using the Canadian Network for Public Health Intelligence (CNPHI), was launched in BC and enteric disease outbreaks are entered by all local health authorities and by the BC Centre for Disease Control (BCCDC) into this system. This CNPHI system is also used by other jurisdictions across Canada.

A gastrointestinal outbreak in the system is defined as one of two types: Community Outbreak: two or more unrelated cases with similar illness that can be epidemiologically linked to one another, i.e., associated by time and/or place and/or exposure and Institution Outbreak: three or more cases with similar illness that can be epidemiologically linked to one another, i.e., associated by exposure within a four-day period in an institutional setting.

All data is entered electronically (retrospectively) and includes information on pathogen, number of cases, hospitalizations, deaths, setting, mode of transmission, source, factors that contributed to the outbreak and interventions. Each local health authority is responsible for entering outbreaks investigated within their jurisdiction into the system. The BCCDC enters multi-regional outbreaks and the Public Health Agency of Canada (PHAC) enters multi-provincial/territorial outbreaks.

This report includes data on reported enteric disease outbreak investigations initiated between 2009 and 2013 in BC. National outbreaks (reported by PHAC) that involved cases residing in BC were also included. Residential facility-based viral outbreaks and outbreaks associated with international travel were excluded.

Data were extracted on March 6, 2014 and for national outbreaks on June 5, 2014. Comparison between outbreaks reported as foodborne and person-to-person transmission was conducted for setting, contributing factors and interventions. Source attribution was conducted using only outbreaks reported as foodborne. Outbreaks were associated with food handlers if a pathogen was identified in a food handler or an infected food handler was identified. Year and month of the outbreak investigation were based on the date the investigation started. Outbreak duration was calculated using the earliest and last symptom onset dates reported.

\section{Results}

There were 104 outbreaks investigated between 2009 and 2013. Ninety-three were reported by BC organizations and 11 were reported by PHAC. There was an average of 21 and median of 22 outbreaks investigated each year, with a range of 16-26 outbreaks per year (Figure 1). There was an approximately $40 \%$ increase in outbreaks investigated in 2011 which was sustained in 2012 and 2013. The annual rate of foodborne outbreaks in BC was 2.8 outbreaks per one million population. 
Figure 1: Number of enteric disease outbreaks reported by year, British Columbia $(\mathrm{N}=104)$

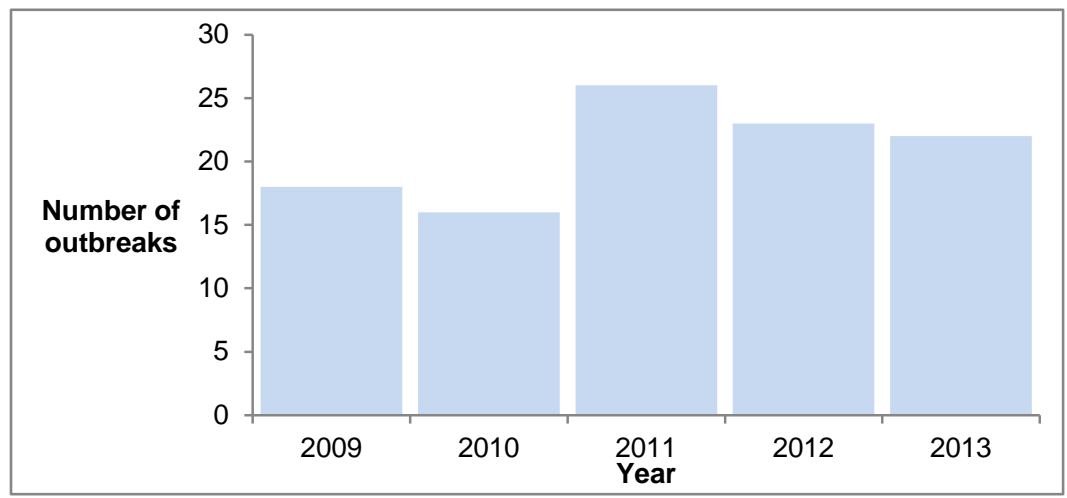

There were 50 (48.1\%) bacterial and $42(40.4 \%)$ viral outbreaks reported. Seventy-nine $(76.0 \%)$ of all outbreaks had a lab-confirmed pathogen identified (Table 1). The pathogens most commonly reported were norovirus, Salmonella and E. coli (Table 2). Enteritidis was the most commonly reported serotype of Salmonella $(\mathrm{n}=13,50.0 \%)$ and all $E$. coli outbreaks were caused by $E$. coli $O 157$.

There were a total of 2,134 outbreak-related (clinical and lab-confirmed) cases (Table 1). The majority were clinically identified (76.4\%) and outbreaks caused by viral pathogens had the largest number and proportion of clinical cases. Of all cases, $108(5.1 \%)$ resulted in hospitalizations. Outbreaks caused by bacteria led to the largest number and proportion of hospitalizations (81,75.0\%). Of the hospitalizations, the pathogens with the largest number and proportion were Salmonella (38, 35.2\%), E. coli $(37,34.3 \%)$ and norovirus (10, 9.3\%). Two deaths were due to a bacterial infection (Table 1), one by botulism and the other by E. coli 0157.

There was an average of 20.3 cases per outbreak. Outbreaks caused by viral pathogens had the largest average number of cases (29.0) and outbreaks caused by yeast/fungi had the smallest (7.0). Outbreak duration had a median of four days. Outbreaks caused by bacterial and parasitic outbreaks had a notably longer duration, 11 and 16 days respectively (Table 1).

Table 1: Characteristics of enteric disease outbreak investigations by pathogen type, British Columbia, 2009-2013

\begin{tabular}{|c|c|c|c|c|c|c|c|}
\hline Characteristic & $\begin{array}{c}\text { Bacterial } \\
(n=50)\end{array}$ & $\begin{array}{l}\text { Viral } \\
(n=42)\end{array}$ & $\begin{array}{l}\text { Parasitic } \\
(n=2)\end{array}$ & $\begin{array}{c}\text { Unknown } \\
(n=4)\end{array}$ & $\begin{array}{c}\text { Toxinl } \\
\text { chemical } \\
(n=5)\end{array}$ & $\begin{array}{l}\text { Yeast/ } \\
\text { fungi } \\
(n=1)\end{array}$ & $\begin{array}{c}\text { Total } \\
(n=104)\end{array}$ \\
\hline $\begin{array}{l}\text { Number (\%) of lab- } \\
\text { confirmed outbreaks }\end{array}$ & $\begin{array}{c}49 \\
(98.0 \%) \\
\end{array}$ & $\begin{array}{c}23 \\
(54.8 \%) \\
\end{array}$ & $\begin{array}{c}2 \\
(100 \%) \\
\end{array}$ & $\begin{array}{c}0 \\
(0 \%) \\
\end{array}$ & $\begin{array}{c}5 \\
(100 \%) \\
\end{array}$ & $\begin{array}{c}0 \\
(0 \%)\end{array}$ & $\begin{array}{c}79 \\
(76.0 \%) \\
\end{array}$ \\
\hline $\begin{array}{l}\text { Total number of lab- } \\
\text { confirmed cases }\end{array}$ & 398 & 80 & 12 & 0 & 12 & 0 & 502 \\
\hline $\begin{array}{l}\text { Total number of } \\
\text { clinical cases }\end{array}$ & 351 & 1138 & 16 & 45 & 75 & 7 & 1632 \\
\hline $\begin{array}{l}\text { Average number of } \\
\text { cases }^{1 /} \text { outbreak }\end{array}$ & 14.9 & 29.0 & 22.0 & 11.3 & 15.4 & 7.0 & 20.3 \\
\hline $\begin{array}{l}\text { Total number and \% } \\
\text { of hospitalizations }\end{array}$ & $\begin{array}{c}81 \\
(75.0 \%) \\
\end{array}$ & $\begin{array}{c}20 \\
(25.0 \%) \\
\end{array}$ & 0 & 0 & 7 & 0 & 108 \\
\hline $\begin{array}{l}\text { Total number and \% } \\
\text { of deaths }\end{array}$ & $2(100 \%)$ & 0 & 0 & 0 & 0 & 0 & 2 \\
\hline $\begin{array}{l}\text { Median duration in } \\
\text { days of outbreak } \\
\text { based on dates of } \\
\text { onset (range) }\end{array}$ & $\begin{array}{c}11 \\
(0-234)\end{array}$ & $\begin{array}{c}4 \\
(0-137)\end{array}$ & 16 & $\begin{array}{c}1 \\
(0-2)\end{array}$ & $\begin{array}{c}0 \\
(0-11)\end{array}$ & 0 & $\begin{array}{c}4 \\
(0-234)\end{array}$ \\
\hline
\end{tabular}

${ }^{1}$ Includes both laboratory confirmed and clinical. 
Table 2: Enteric disease outbreaks by pathogen, British Columbia, 2009-2013

\begin{tabular}{|c|c|}
\hline Pathogen & Number (\%) \\
\hline Norovirus & $38(36.5 \%)$ \\
\hline Salmonella & $26(25 \%)$ \\
\hline Escherichia coli & $12(11.5 \%)$ \\
\hline Clostridium botulinum & $3(2.9 \%)$ \\
\hline Campylobacter & $2(1.9 \%)$ \\
\hline Hepatitis A & $2(1.9 \%)$ \\
\hline Histamine poisoning & $2(1.9 \%)$ \\
\hline Shellfish poisoning $^{1}$ & $2(1.9 \%)$ \\
\hline Staphylococcus & $2(1.9 \%)$ \\
\hline Other $^{2}$ & $7(6.7 \%)$ \\
\hline Unknown $^{3}$ & $8(7.7 \%)$ \\
\hline Total & 104 \\
\hline
\end{tabular}

Foodborne exposure was the most common mode of transmission (59.6\%) (Table 3). Of the 62 foodborne outbreaks, $40(64.5 \%)$ were caused by bacteria. The most common cause was Salmonella $(n=22)$. Of the person-to-person outbreaks, 22 (95.7\%) were caused by viruses, all norovirus.

Food service establishments were the most common outbreak setting (33.7\%), followed by community (24.0\%) and private functions (12.5\%) (Table 3). Outbreaks at food service establishments were caused by food as well as person-to-person transmission. Of the eight person-to-person outbreaks in food service establishments, only two documented ill food handlers as the source. Person-to-person outbreaks had a higher proportion of outbreaks associated with facilities (e.g., hospitals, schools, hotels) (Table 3).

Table 3: Enteric disease outbreaks by mode of transmission and setting, British Columbia, 2009-2013

\begin{tabular}{|c|c|c|c|c|c|c|}
\hline $\begin{array}{l}\text { Outbreak } \\
\text { setting }\end{array}$ & Foodborne & $\begin{array}{c}\text { Person-to- } \\
\text { person }\end{array}$ & Unknown & Other $^{1}$ & Waterborne & Total \\
\hline $\begin{array}{l}\text { Food service } \\
\text { establishment }\end{array}$ & $24(38.7 \%)$ & $8(34.8 \%)$ & $1(8.3 \%)$ & $2(25 \%)$ & $0(0 \%)$ & $35(33.7 \%)$ \\
\hline Community & $17(27.4 \%)$ & $2(9 \%)$ & $5(41.7 \%)$ & $1(12.5 \%)$ & $0(0 \%)$ & $25(24 \%)$ \\
\hline Private function & $10(16.1 \%)$ & $3(13 \%)$ & $0(0 \%)$ & $0(0 \%)$ & $0(0 \%)$ & $13(12.5 \%)$ \\
\hline Institutional $^{2}$ & $5(8.1 \%)$ & $4(17.4 \%)$ & $1(8.3 \%)$ & $1(12.5 \%)$ & $0(0 \%)$ & $11(10.6 \%)$ \\
\hline $\begin{array}{l}\text { Non-Institutional } \\
\text { facility }^{3}\end{array}$ & $0(0 \%)$ & $3(13.0 \%)$ & $1(8.3 \%)$ & $0(0 \%)$ & $0(0 \%)$ & $4(3.8 \%)$ \\
\hline $\begin{array}{l}\text { Recreational } \\
\text { facility }\end{array}$ & $0(0 \%)$ & $2(8.7 \%)$ & $0(0 \%)$ & $1(12.5 \%)$ & $0(0 \%)$ & $3(2.9 \%)$ \\
\hline $\begin{array}{l}\text { More than one } \\
\text { setting }\end{array}$ & $3(4.8 \%)$ & $1(4.3 \%)$ & $1(8.3 \%)$ & $1(12.5 \%)$ & $0(0 \%)$ & $6(5.8 \%)$ \\
\hline Other & $2(3.2 \%)$ & $0(0 \%)$ & $2(16.6 \%)$ & $2(25 \%)$ & $0(0 \%)$ & $6(5.8 \%)$ \\
\hline Unknown & $1(1.6 \%)$ & $0(0 \%)$ & $0(0 \%)$ & $0(0 \%)$ & $0(0 \%)$ & $1(1 \%)$ \\
\hline Total & $62(59.6 \%)$ & $23(22.1 \%)$ & $11(10.6 \%)$ & $8(7.7 \%)$ & $0(0 \%)$ & 104 \\
\hline
\end{tabular}

A food source was identified in $45(72.6 \%)$ of the foodborne outbreaks (Table 4) and were most often reported to be fruits and vegetables, meat and seafood. Fruits and vegetables, which included fresh, frozen 
and canned fruits and vegetables, were associated with the largest number of different pathogens $(n=5)$. Among the 14 outbreaks caused by Salmonella, where a source was identified, eggs were the main cause in five of the reported outbreaks (35.7\%). The only dairy-related outbreak was caused by unpasteurized cheese. Norovirus caused ten foodborne outbreaks and a source was identified in nine of them. Norovirus outbreaks were caused by seafood, mixed foods, fruit and vegetables. In eight of the outbreaks with a source and the single outbreak without a source, an infected food handler was identified as the contributing factor (data not shown).

Table 4: Foodborne outbreaks by pathogen and source, British Columbia, 2009-2013

\begin{tabular}{|c|c|c|c|c|c|c|c|c|c|c|}
\hline Food Type & $\begin{array}{c}\text { Clostridium } \\
\text { botulinum }\end{array}$ & $\begin{array}{c}\text { Escherichia } \\
\text { coli }\end{array}$ & $\begin{array}{c}\text { Hepatitis } \\
\text { A }\end{array}$ & $\begin{array}{l}\text { Noro- } \\
\text { virus }\end{array}$ & Salmonella & $\begin{array}{c}\text { Shellfish } \\
\text { poisoning }{ }^{1}\end{array}$ & $\begin{array}{l}\text { Staphylo- } \\
\text { coccus }\end{array}$ & Other $^{2}$ & $\begin{array}{c}\text { Un- } \\
\text { known }\end{array}$ & Total \\
\hline $\begin{array}{l}\text { Fruit and } \\
\text { vegetables }\end{array}$ & 1 & 1 & $1(4)$ & 3 & 3 & 0 & 0 & 0 & 1 & 10 \\
\hline Meat $^{3}$ & 0 & 4 & 0 & 0 & $4(5)$ & 0 & 1 & 0 & 0 & 9 \\
\hline Seafood & 1 & 0 & 0 & $2(6)$ & 0 & $4(7)$ & 0 & 0 & 1 & 8 \\
\hline $\begin{array}{l}\text { Mixed } \\
\text { Foods }\end{array}$ & 0 & 0 & 0 & 3 & 0 & 0 & 1 & 1 & 2 & 7 \\
\hline Eggs & 0 & 0 & 0 & 0 & $5(8)$ & 0 & 0 & 0 & 0 & 5 \\
\hline $\begin{array}{l}\text { Dairy } \\
\text { Products }\end{array}$ & 0 & 1 & 0 & 0 & 0 & 0 & 0 & 0 & 0 & 1 \\
\hline $\begin{array}{l}\text { Sauces/ } \\
\text { Condiments }\end{array}$ & 1 & 0 & 0 & 0 & 0 & 0 & 0 & 0 & 0 & 1 \\
\hline Unknown & 0 & 2 & 1 & 2 & 10 & 0 & 0 & 4 & 2 & 21 \\
\hline Total & 3 & 8 & 2 & 10 & 22 & 4 & 2 & 5 & 6 & 62 \\
\hline
\end{tabular}

${ }^{1}$ PSP (1), DSP (1), Histamine (2)

${ }^{2}$ Aeromonas (1) Campylobacter (1), C. perfringens (1), Cyclospora (1), Shigella (1)

${ }^{3}$ Included beef (2) chicken (3), deli meat (1), turkey (1) veal liver (1) and haggis (1)

Foods which led to the largest number of cases were caused by eggs $(n=196)$, mixed foods $(n=168)$ and seafood $(n=139)$. These foods accounted for $45.5 \%$ of all foodborne outbreak cases.

The most common contributing factors among foodborne outbreaks were associated with the process of food production (e.g., critical control point failures, inadequate cooking, cross contamination). Among person-to-person outbreaks, common contributing factors were related to exposure to another ill person, another case or a contaminated environment (Table 5).

Table 5: Contributing factors for foodborne and person-to-person outbreaks, British Columbia, 2009-2013

\begin{tabular}{|l|c|c|}
\hline Contributing Factor & Foodborne (N=62) & Person to person (N=23) \\
\hline Critical control point failure & $17(27.4 \%)$ & $1(4.3 \%)$ \\
\hline Cross contamination & $11(17.7 \%)$ & $3(13 \%)$ \\
\hline $\begin{array}{l}\text { Improper temperature (e.g., cooling or hot } \\
\text { holding) }\end{array}$ & $12(19.4 \%)$ & 0 \\
\hline Inadequate re-heating & $1(1.6 \%)$ & 0 \\
\hline Infected food handler & $11(17.7 \%)$ & $2(8.7 \%)$ \\
\hline Inadequate cooking & $12(19.4 \%)$ & 0 \\
\hline Poor hygiene & $8(12.9 \%)$ & $2(26.1 \%)$ \\
\hline Personal caregiver contact & 0 & $7(30.4 \%)$ \\
\hline Exposure to confirmed/probable cases & $1(1.6 \%)$ & $3(13 \%)$ \\
\hline Inadequate environmental sanitation & $5(8 \%)$ & \\
\hline
\end{tabular}

The most common interventions used to control outbreaks were education, sanitizing the facility and cohorting cases/staff (Table 6). For person-to-person outbreaks education and sanitizing the facility were the most common interventions. Foodborne outbreaks most often reported a food recall and closing a facility as an intervention, compared to person-to-person outbreaks which reported restricting admissions/transfers or visitors and cohorting cases or staff. Seven foodborne outbreaks reported a policy change as an intervention. A press release was issued for ten outbreaks; nine foodborne and one person-to-person 
outbreak. Education was the most common intervention used across all food sources. Recalls were used most often for meat (5), seafood (2) and fruit (2). Sanitizing the facility was performed in outbreaks caused by eight different food sources.

Table 6: Interventions used to control foodborne and person-to-person outbreaks, British Columbia, 2009-2013

\begin{tabular}{|c|c|c|c|c|}
\hline Intervention & Foodborne $(\mathrm{N}=62)$ & $\begin{array}{c}\text { Person-to-person } \\
(\mathrm{N}=23)\end{array}$ & $\begin{array}{l}\text { Other } \\
(\mathrm{N}=20)\end{array}$ & Total \\
\hline Education & $36(59 \%)$ & $15(24.6 \%)$ & $10(16.4 \%)$ & 61 \\
\hline Sanitize facility & $13(40.6 \%)$ & $9(28.1 \%)$ & $10(31.3 \%)$ & 32 \\
\hline Cohort cases or staff & $2(11.8 \%)$ & $8(47.1 \%)$ & $7(41.2 \%)$ & 17 \\
\hline Exclude staff & $7(46.7 \%)$ & $5(33.3 \%)$ & $3(20 \%)$ & 15 \\
\hline Recall & $12(100 \%)$ & 0 & 0 & 12 \\
\hline $\begin{array}{l}\text { Restrict facility } \\
\text { admissions/transfers and/or } \\
\text { visitors }\end{array}$ & $2(18.2 \%)$ & $7(63.6 \%)$ & $2(18.2 \%)$ & 11 \\
\hline Press release & $9(90 \%)$ & $1(10 \%)$ & 0 & 10 \\
\hline Close facility & $6(66.7 \%)$ & $1(11.1 \%)$ & $2(22.2 \%)$ & 9 \\
\hline Policy change & $7(100 \%)$ & 0 & 0 & 7 \\
\hline $\begin{array}{l}\text { Immunize susceptible } \\
\text { contacts }\end{array}$ & $1(100 \%)$ & 0 & 0 & 1 \\
\hline Boil water advisory & 0 & 0 & 0 & 0 \\
\hline
\end{tabular}

\section{Discussion}

Over the five year time period, a notable number of reported enteric disease outbreaks caused a significant burden of illness in BC. An increase in the number of outbreaks reported between 2011 and 2013 likely reflects efforts to improve reporting of outbreaks. This also included a decision to stop reporting viral outbreaks in residential-facilities as of July 2011 , which may have improved the reporting of outbreaks caused by other modes of transmission settings and sources. This exclusion does limit the ability to count the total number of enteric disease outbreaks caused by all sources, pathogens and settings at a provincial level.

Norovirus was the most common outbreak cause followed by Salmonella. Both of these are in the top five pathogens causing domestically-acquired foodborne illness in BC (unpublished data. BC Centre for Disease Control and Public Health Agency of Canada, 2014). These are also the most common pathogens that cause outbreaks in the US (2). Viral outbreaks caused the largest number of cases and bacterial outbreaks were responsible for more hospitalizations and deaths. Bacterial, parasitic and toxin/chemical outbreaks were more frequently lab-confirmed compared to viral outbreaks. This is likely because viral outbreaks may be investigated and managed without laboratory diagnosis, are self-limited and not associated with severe presentation.

The proportion of hospitalized (3.8\%) is comparable with the US (3.4\%) and lower than European data $(13.8 \%)(2,10)$. The case-fatality rate $(0.1 \%)$ is lower than the US (0.7\%) but slightly higher than European data $(0.03 \%)(2,10)$. In the US and BC, Salmonella, E. coli and norovirus caused the largest number and proportion of hospitalizations. These similarities may be due to the fact that in both countries more severe cases are more likely to be tested and lab-confirmed. The difference between the proportion of hospitalization in Europe may be impacted by the more severe diseases included such as toxoplasmosis and tularaemia. The difference in proportion of deaths between BC, the US and Europe may be due to small numbers.

The annual rate of foodborne outbreaks in BC (2.8 per one million population) is lower than the US rate of 4.8 per one million population (2). This may be due to different systems and methods of reporting.

Food service establishments were the most common setting for all outbreaks (34\%) in BC. Among Salmonella outbreaks in BC, food service establishments were still the most common setting and made up 
$47.6 \%$ of outbreaks. This is similar to the US where food prepared in a restaurant or deli was also the most common setting for foodborne outbreaks with a single place of food preparation, although these accounted for a larger proportion (68\%). New Zealand reported commercial food operations were the second most common location for Salmonella outbreaks (31\%) while the home was the most common setting reported $(2,9)$.

The majority of outbreaks were foodborne (59.6\%) with Salmonella causing the largest proportion of foodborne outbreaks (35.8\%). Of the Salmonella outbreaks, $84.6 \%$ were foodborne which is higher than New Zealand (63\%) (9). Salmonella was also the most common cause of foodborne outbreaks reported in Europe (10).

The source of exposure was identified for $72.6 \%$ of foodborne outbreaks. This is higher than what was previously reported for $\mathrm{BC}$ and other jurisdictions $(11,12)$. This may be because outbreaks with an identified source are more likely to be reported. Produce, meat and seafood were the most common foods $(16 \%, 15 \%$ and $13 \%$ respectively). Produce caused more outbreaks than meat, eggs and dairy products. US analysis identified meat products as the top source of foodborne outbreaks, with a change in more recent years to a larger proportion of outbreaks caused by leafy vegetables (2). Produce-associated outbreaks have increased in North America $(13,14,15)$. Monitoring these trends through outbreak data will enable re-prioritization of prevention efforts.

These data show an association between Salmonella and eggs. During this time period, BC investigated a large, protracted outbreak of Salmonella Enteritidis (SE) associated with eggs (8). SE outbreaks were still most commonly caused by eggs in the US, but a decrease in Salmonella outbreaks caused by eggs over time was noted (2). European data demonstrated that eggs and egg products were the most important food vehicles for Salmonella (10). Food-specific attribution has been done previously in Canada twice using expert elicitation and once using outbreak data $(16,17,18)$. All three identified poultry meat as the most likely source of Salmonella infections. Eggs were identified as the second most common source among the expert elicitations. The expert elicitations also demonstrate a large proportion of enteric bacterial infections are attributed to produce which is comparable with the findings of this study $(16,17)$.

Outbreaks are a validated source attribution data. Strengths of outbreak data include: a clear link between the pathogen and food, availability of data over time and the inclusion of a wide-variety of food items that may not be represented using other methods (9). However, not all outbreaks are investigated and reported and data from all systems may not be directly comparable $(19,20)$.

Food handlers were identified as the contributing factor of nine norovirus outbreaks. This emphasizes the need for improved education and resources for food handlers and their employers and interventions to identify and exclude ill workers in a timely way.

Education and sanitizing the facility were the most commonly used interventions. Other interventions, such as recalls or policy changes are applied less often as they require identification of a specific food source or issue. Interventions are impacted by the setting they occur in, particularly those related to institutional settings where person-to-person transmission may be more common. However, it is not possible to comment on whether the interventions used were effective at preventing further cases as dates of the interventions were not available. Literature is limited regarding the effectiveness of outbreak interventions, particularly those that are widespread or community-based. Further investigation would assist decision-making, resource allocation and outbreak investigations.

While this analysis has demonstrated that the surveillance system is meeting its objectives there are limitations. The focus is on a small number of outbreaks which were reported over a short period of time. Therefore, more specific analysis by pathogen or by assessing trends over time is not possible. This limitation will be overcome eventually as more outbreaks are reported. In addition, the system relies on public health authorities to enter outbreaks in their jurisdiction. While processes have been established to 
verify entry of known outbreaks, it is possible that not all outbreaks are identified, investigated and reported. Finally, decentralized data entry may also impact data quality. When data quality issues are identified, standards or system improvements are developed.

\section{Conclusion}

Surveillance of enteric disease outbreaks in BC provides information on trends, sources, settings and modes of transmission. These data have been used to inform technical and risk assessment, reports and publications. Further data and analysis could be used to inform local food safety priorities, develop messaging targeting pathogen-food combinations or direct resources at specific interventions.

Ongoing reporting and analysis of outbreak data in BC will allow for improved assessment of trends in sources and pathogens over time and further work to understand the effectiveness outbreak of interventions.

\section{Acknowledgements}

The authors would like to acknowledge the contribution of their Health Authority colleagues in entering outbreaks and BC laboratories and the BC Public Health Microbiology and Reference Laboratory for their diagnostic support.

\section{Conflict of interest}

None.

\section{Funding}

None.

\section{References}

(1) Public Health Agency of Canada. Foodnet Canada 2013 Short Report [Internet]. Ottawa ON: PHAC; September 2014. http://www.phac-aspc.gc.ca/foodnetcanada/report-rapport-2013-eng.php.

(2) Gould H, Walsh KA, Vieira AR, Herman K, Williams IT, Hall AJ, Cole D. Surveillance for foodborne disease outbreaks-United States, 1998-2008. MMWR. 2013 June 28;62(2).

(3) Public Health Act Communicable Disease Regulation. BC Reg. 4/83. List of reportable diseases. British Columbia Health Act Communicable Disease Regulation [Internet]. http://www.bclaws.ca/Recon/document/ID/freeside/12_4_83.

(4) Swinkels HM, Kuo M, Embree G, Fraser Health Environmental Health Investigation Team, Andonov A, Henry B, Buxton JA. Hepatitis A outbreak in British Columbia, Canada: The roles of established surveillance, consumer loyalty cards and collaboration, February to May 2012. Eurosurveillance. 2014;19(18).

(5) Taylor J, Galanis E, Wilcott L, Hoang L, Stone J, Ekkert J, Quibell D, Huddleston M, McCormick R, Whitfield Y, Adhikari B, Grant CC, Sharma D, Salmonella Chester Outbreak Investigation Team. An outbreak of Salmonella Chester infection in Canada: Rare serotype, uncommon exposures and unusual population demographic facilitate rapid identification of food vehicle. J Food Prot. 012;75(4):738-742.

(6) McIntyre L, Galanis E, Mykytczuk O, Buenaventura E, Wong J, Prystajeky N, Ritson M, Stone J, Moreau D, Youssef A, Outbreak Investigation Team. Multiple clusters of norovirus among shellfish consumers linked to symptomatic oyster harvesters. J Food Prot. 2012;75(9):1715-1720.

(7) Taylor M, McIntyre L, Ritson M, Stone J, Bronson R, Bitzikos O, Rourke W, Galanis E, Outbreak Investigation Team. Outbreak of diarrhetic shellfish poisoning associated with mussels, British Columbia, Canada. Mar. Drugs. 2013;11(1):669-1676.

(8) Taylor M, Leslie M, Ritson M, Stone J, Cox W, Hoang L, Galanis E, Outbreak Investigation Team. Investigation of the concurrent emergence of Salmonella enteritidis in humans and poultry in British Columbia, Canada, 20082010. Zoonoses Public Health. 2012;59(8):584-592.

(9) King N, Lake R, Campbell D. Source attribution of nontyphoid salmonellosis in New Zealand using outbreak surveillance data. J Food Prot. 2011;74(3):438-445. 
(10) European Food Safety Authority, European Centre for Disease Prevention and Control. The European Union summary report on trends and sources of zoonoses, zoonotic agents and food-borne outbreaks in 2013 [Internet]. Parma, Italy: EFSA; 2015.

http://ecdc.europa.eu/en/publications/Publications/EU-summary-report-trends-sources-zoonoses-2013 pdf.

(11) Taylor M, Galanis E. Establishing criteria to initiate enteric outbreak investigations in British Columbia. Can Commun Dis Rep 2014;40(S-1).

(12) Gaulin C, Currie A, Gravel G, Hamel M, LeBlanc MA, Ramsay D, Bekal S. Summary of 11 years of enteric outbreak investigation and criteria to initiate an investigation, Province of Quebec, 2002 through 2012. J Food Prot. 2014;9:1448-1648.

(13) Berger CN, Sodha SV, Shaw RK, Griffin PM, Pink D, Hand P, Frankel G. Fresh fruit and vegetables as vehicles for the transmission of human pathogens. Environ Microbiol. 2010;12(9):2385-2397.

(14) Lynch MF, Tauxe RV, Hedberg CW. The growing burden of foodborne outbreaks due to contaminated fresh produce: Risks and opportunities. Epidemiol Infect. 2009;137(3):307-315.

(15) Sivapalaingam S, Friedman CR, Cohen L, Tauxe RV. Fresh produce: A growing cause of outbreaks of foodborne illness in the United States, 1973 through 1997. J Food Prot. 2004;67(10):2342-2352.

(16) Butler A, Pintar K, Thomas MK. Estimating the relative role of various subcategories of food, water and animal contact transmission of 28 enteric diseases in Canada. Forthcoming 2015.

(17) Davidson VJ, Ravel A, Nguyen TN, Fazil A, Ruzante JM. Food specific attribution of selected gastrointestinal illnesses: Estimates from a Canadian Expert Elicitation Survey. Foodborne Pathog Dis. 2011;8(9):983-995.

(18) Ravel A, Davidson VJ, Ruzante JM, Fazil A. Foodborne proportion of gastrointestinal illness: Estimates from a Canadian expert elicitation survey. Foodborne Pathog Dis. 2010;7:1463-1472.

(19) Pires SM, Vieira AR, Hald T, Cole D. Source attribution of human salmonellosis: An overview of methods and estimates. Foodborne Pathog Dis. 2014;1:667-676.

(20) US Food and Drug Administration. FDA, federal partners develop improved method for attributing foodborne illness: Constituent update [Internet]. Washington DC: USFDA; Feb 24, 2015. http://www.fda.gov/Food/NewsEvents/ConstituentUpdates/ucm435256.htm. 